Original article

Received: 16 October 2016 / Accepted: 27 May 2017

\title{
ACCURACY INVESTIGATION OF CREATING ORTHOPHOTOMAPS BASED ON IMAGES OBTAINED BY APPLYING TRIMBLE-UX5 UAV
}

\author{
Volodymyr Hlotov $^{1}$, Alla Hunina ${ }^{1}$, Zbigniew Siejka ${ }^{2}$ \\ 1) National University Lviv Polytechnic, Institute of Geodesy \\ 2) University of Agriculture in Krakow
}

\begin{abstract}
The main purpose of this work is to confirm the possibility of making largescale orthophotomaps applying unmanned aerial vehicle (UAV) TrimbleUX5. A planned altitude reference of the studying territory was carried out before to the aerial surveying. The studying territory has been marked with distinctive checkpoints in the form of triangles $(0.5 \times 0.5 \times 0.2 \mathrm{~m})$. The checkpoints used to precise the accuracy of orthophotomap have been marked with similar triangles. To determine marked reference point coordinates and check-points method of GNSS in real-time kinematics (RTK) measuring has been applied. Projecting of aerial surveying has been done with the help of installed Trimble Access Aerial Imaging, having been used to run out the UX5. Aerial survey out of the Trimble UX5 UAV has been done with the help of the digital camera SONY NEX-5R from $200 \mathrm{~m}$ and $300 \mathrm{~m}$ altitude. These aerial surveying data have been calculated applying special photogrammetric software Pix 4D. The orthophotomap of the surveying objects has been made with its help. To determine the precise accuracy of the got results of aerial surveying the checkpoint coordinates according to the orthophotomap have been set. The average square error has been calculated according to the set coordinates applying GNSS measurements. A-priori accuracy estimation of spatial coordinates of the studying territory using the aerial surveying data have been calculated: $m_{X}=0.11 \mathrm{~m}, m_{Y}=0.15 \mathrm{~m}, m_{Z}=0.23 \mathrm{~m}$ in the village of Remeniv and $m_{X}=0.26 \mathrm{~m}, m_{Y}=0.38 \mathrm{~m}, m_{Z}=0.43 \mathrm{~m}$ in the town of Vynnyky. The accuracy of determining checkpoint coordinates has been investigated using images obtained out of UAV and the average square error of the reference points. Based on comparative analysis of the got results of the accuracy estimation of the made orthophotomap it can be concluded that the value the average square error does not exceed a-priori accuracy estimation. The possibility of applying Trimble UX5 UAV for making large-scale orthophotomaps has been investigated. The aerial surveying output data using UAV can be applied for monitoring potentially dangerous for people objects, the state border controlling, checking out the plots of settlements. Thus, it is
\end{abstract}


important to control the accuracy the got results. Having based on the done analysis and experimental researches it can be concluded that applying UAV gives the possibility to find data more efficiently in comparison with the land surveying methods. As the result, the Trimble UX5 UAV gives the possibility to survey built-up territories with the required accuracy for making orthophotomaps with the following scales 1: 2000, 1: 1000, 1: 500.

Keywords: unmanned aerial vehicle, aerial survey, digital camera, orthophotomap, planned altitude reference.

\section{Introduction}

Nowadays, unmanned aerial vehicle (UAV) is one of the most intensively developed part of aviation technique and its applying for making large-scale topographical plans is of great importance and can become potentially an alternative to the terrestrial geodetic methods. It is explained by the fact that UAV is equipped with appropriate means for aerial surveying and that's why it is more economically efficient in comparison with the terrestrial surveying methods which are applied usually for much longer period of time. The UAV with fixed wings (Wang, 2004), multi-rotors (Haarbrink, 2008; Nebiker, 2008; Steffen 2008) and modern auto- gyroscopic UAV have become the most efficient and reliable platforms for studying. At the beginning of the second decade of the 21st century, more than 50 firms all over the world have already constructed and produced over 150 types of the UAV. Due to automation, improvement of the computer systems and geotechnologies the leading world companies have established new criteria of remote sensing and mapping which are based on low altitude surveying and on application of geospatial information (Vovk A. et al., 2015; Mayr, 2013; Petrie, 2013). All these facts have been in accordance to the requirements of making large-scale maps for several years already. For example, the Gatewing company is focused on the aerial surveying for geospatial mapping. Application of UAV provides the access to a great number of information.

The authors of publications (Haarbrink, 2008; Hartley \& Zisserman, 2003; Vasuki, 2014) emphasize that three main positive aspects of the UAV application are: automation of the surveying processes to obtain images out of different altitudes; great flexibility which gives the possibility to work with different types of images (visible, infrared or thermal) and to use any types of cameras (calibrated or uncalibrated); obtaining high-quality and reliable results. However, there are some other positive aspects which have not been considered yet, such as ecological safety of the flights and the possibility of detailed (small objects and plots) surveying where it is not profitable or technically possible to do it by other means. That is why the UAV is more often applied for geodetic and cartographic production, especially the works concerning of safety arises depended on safety of highways, railroads and other dangerous or inaccessible places.

In their article (Fernández-Hernandez, 2015) the authors describe a photogrammetric unit for constructing 3D model of high-resolution. That equipment was chosen to make an orthophotomap and digital terrain model (DTM) of a Celtic settlement in Las Cogotas (Spain). The control measurement devices were a Microdrone md4-1000 with the digital camera Olympus EPL-2 and the Global Positioning System Leica 1200 Global which operates in real-time kinematics (RTK). The chosen UAV had four rotating wings affording a stable flight at low altitudes. The UAV had navigation sensors (a gyroscope, accelerometer, a magnetometer and a barometer) and secondary sensors (a hygrometer and a thermometer). The flight 
was planned at $65 \mathrm{~m}$ altitude over the area of approximately 5 hectares. The route was covered by 30 images in three east-west directions (10 images for each direction). The minimum forward overlap was $80 \%$ and minimum side overlap was $40 \%$. The camera obtained ISO sensitivity out of 200 to get less speckle images, moderation focus was F/7.1 with automatic exposure about 1/640 of a second. The working process consisted of the following steps: route planning, aerial survey, image processing, generalization of surface density, orthophotomap making, accuracy estimation. The accuracy of plane coordinates of created model was $5 \mathrm{~cm}$, its altitude accuracy was $6 \mathrm{~cm}$. The results of photogrammetric image processing of the archaeological excavations obtained out of the UAV showed that the approach suggested by the authors was semi-automatic, not expensive, effective and qualitative. However, it was considered that such work did not solve the problem of automatic identification of checkpoints.

The authors (Haarbrink, 2008) in their article presented a project where aerial survey was made at the plot of $200 \times 300 \mathrm{sq}$. $\mathrm{m}$. with the help of a helicopter which was used for mapping out of the altitude of $100 \mathrm{~m}$ for 5 minutes. As the result the orthophotomaps, three-dimensional vector maps and DTM with a density of approximately 50 points per square meter were created. The average square error of altitudes of the created DTM is $4 \mathrm{~cm}$, and of plane coordinates is $2 \mathrm{~cm}$. Though, the authors calculated plane and altitude coordinate errors, but the a-priori accuracy estimation and comparative analysis of the set coordinates have not been determined.

The octocopter with the possibility of a planned altitude referencing has been presented in the article by Rehak in 2013. It is equipped with eight engines to increase lifting capacity and a parachute for people safety and the micro-UAV itself in case of emergency glide path in an unpredictable place. The constructing peculiarities of the UAV give the possibility of mounting all necessary devices for the aerial surveying. The advantage of such system is its high mobility, work flexibility, and possibility to get image data without the necessity to mark ground reference points. Such range of work saves the aerial surveying time. The suggested UAV has been constructed based on open output code of autopilot of double-frequency GPS and the cameras fixed to the cardan joint, which reduces considerably the vibration effect of the wind and keeps them in vertical position (such position is very important for the aerial surveying). The average square error of plain checkpoint coordinates does not exceed $4.6 \mathrm{~cm}$. But there is no comparative analysis of the results of aerial surveying accuracy (with and without the gyrostabilizing platform) in the article. But the wind impact on the cardan joint must be taken into consideration.

In the articles (Hadjimitsis, 2004; Mahiny, 2007; Smith, 1999) the authors emphasize that the output image data depend on and are changed under the influence of such factors as meteor-conditions and camera technical characteristics. The impact of wind and thermal effects can easily become the reason for large angular elements of external orientation up to decade of degrees. That's why it is a problem for the traditional analytical photogrammetric processing.

The problem of application of ultra-light UAV in combination with a compact digital camera is considered in the publication by Vallet in 2011 . It gives the possibility to provide with cartographic products such as digital terrain models and orthophotomaps. The quality of the cartographic products done by aerial surveying depends on the methods of image processing. But such factor as the distortions caused by poor quality of the objective lens has not been taken into consideration by 
the author. Thus, it causes the appearance of cross-parallax and as the result prevents to create stereomodels.

The results of practical studies of UAV application for mapping are shown in the article (Catur, 2015; Mitch, 2010). The system consists of UAV, digital camera, digital photogrammetric data processing which includes algorithms structure and free open access to GIS visualization. This system gives the possibility to carry out surveying with spatial resolution up to $10 \mathrm{~cm}$ and plot measuring. The main output data of the system are orthophotomaps and digital terrain model (DTM). A part of the obtained orthophotomap data is used to establish the cadastral boundaries and for vegetation monitoring. The orthophotomap provides visual of certain trees' structure decryption, plants' density and plot area. At the same time digital terrain models (DTM) provide information of trees' height and land topography with accuracy of 3 to 6 pixels or 0.5 to $2.5 \mathrm{~m}$. The accuracy of the plane coordinates is from 10 to $40 \mathrm{~cm}$. The problem of improving the process of conducting orthophotomaps in order to enhance the accuracy has not been considered probably.

Such authors as (Bajwa, 2010; Klinken, 2007; Sandmann, 2003; Petrie, 2013; Zhang, 2002; Whelan, 2010) have applied the aerial surveying data for vegetation monitoring. The basis of it is management based on observations and reaction to changing the surveying object. Monitoring gives the possibility to optimize production efficiency by minimizing the environment impact. However, the obtained orthophotomaps with the resolution from 1 to $10 \mathrm{~m}$ must be insufficient for identification and classification of some vegetation types. Thus, UAV as the remote sensing system must have such characteristics as economic effectiveness, manufacturing velocity, easy exploitation, accuracy of orthophotomap creations.

The article by Maslyanko in 2014 describes the development of remote sensing system method which is the basis for unmanned aerial vehicle. It gives a brief overview of UAV, technology of digital surface model (DSM) using the materials of digital aerial surveying and describes the prospects of digital surface model (DSM) application for deciding the surveying tasks. The accuracy estimation of the obtained digital surface model (DSM) has been done by comparison of the two digital surface model (DSM). They have been obtained out of the aerial surveying data while processing and applying the Photo Scan Pro software. They have been constructed on the basis of the surface tacheometer surveying. The analysis of the done accuracy estimation has shown that the differences of the coordinates in the overlapping areas while creating models of different aerial surveying territories are from 0.02 to $0.08 \mathrm{~m}$ at the aerial surveying altitude from 150 to $250 \mathrm{~m}$. That article does not present any plan of the aerial surveying works and its implementation, and the importance of getting data out of UAV. The experience has shown that planning of the aircraft routes and aerial surveying project real time management play an important role in achieving the productive results and safety surveying.

Some aspects of processing digital images obtained out of UAV are shown in the article written by Mikrut S. in 2016. The author compares images taken from the manned aircraft and from the UAV. The flight has been made over Tokarnia Village Museum (which is $0.5 \mathrm{sq}$. km.). Based on the results of the surveying DTM and orthophotomaps of the studying area have been created. To compare the accuracy of the results obtained from the two flights reference and checkpoints have been used and the average square error has been calculated.

The results obtained out of UAV images have not been worse than those obtained from the classical aerial surveying. The average square error in checkpoints has 
been $m_{X}=0,030 \mathrm{~m}$ and $m_{Y}=0,038 \mathrm{~m}$. The average square error in checkpoints has been $m_{X}=0,014$ and $m_{Y}=0,031$ using the classical technology.

The average square error in checkpoints has been $m_{X}=0,017 \mathrm{~m}$ and $m_{Y}=0,022$ $\mathrm{m}$, the average square error in checkpoints has been $m_{X}=0,019$ and $m_{Y}=0,022 \mathrm{~m}$ using UAV technology. It means that data obtained out of UAV can be applied for conducting orthophotomaps. In addition, the applying UAV is cheaper in comparison with classical aerial surveying.

An economical-effective small in size UAV has been shown in the publication by Coppa in 2009. It has been used for collecting and connecting digital images during the flight at low altitude over the limited in size area. The results of the management system designed for flight simulation using autonomic control system which must be applied for the helicopter model. The average square error is $m_{X}=0.43 \mathrm{~m}, m_{Y}=0.70$ $\mathrm{m}, m_{Z}=0.25 \mathrm{~m}, \omega=1^{\circ}, \alpha=0.5^{\circ}, \mathrm{X}=3^{\circ}$. Construction of the artificial surrounding allows to estimate the main points of the complex control system in order to avoid damaging of the fragile and expensive instruments which have been installed at the helicopter model and thus, test the synchronization methods of GPS cameras. Such images after photogrammetric processing are used to create the digital terrain models, orthophotomaps and other types of GIS input data which can be used for purposes connected with land management.

Having analyzed different sources of information it can be stated that the chosen object of study is up-to-date because it is discussed in a large number of foreign and Ukrainian publications.

\section{The purpose and methodology of studying}

The purpose of this study is to confirm the possibility of applying UAV for making large-scale orthophotomaps.

The surveying object is the territory of the cottage settlement with the area of 0,5 square $\mathrm{km}$. near the village of Remeniv in Kamyanka-Buska district, Lviv region which has altitude difference $20 \mathrm{~m}$, and the north-eastern part of the town of Vynnyky ( its area is 1 square $\mathrm{km}$ ).

The entire working process consists of the following steps (Fig.1):

Calculation of a-priori accuracy estimation

Projecting of aerial surveying routes

Applying of planned altitude reference

Aerial surveying applaying UAV

Processing of images and creating orthophotomaps and DSM

Accuracy estimation of the obtained results

Fig. 1. Technological scheme of aero-surveying process 
To confirm the possibility of using digital stereo-photogrammetric method the apriori accuracy estimation of spatial area coordinates has been calculated. The average square error is calculated by the formulas (Vovk A. et al., 2015).

For preparative project work Trimble Access Aerial Imaging software has been installed in the field controller Trimble Tablet which helps to manage UX5. For discharged planned altitude reference of the surveying object 15 reference and 123 checkpoints in Remeniv have been set at the territory and around the settlement. 13 reference, 113 checkpoints have been set in Vynnyky too. The marked reference points in the form of angles $(0.5 \times 0.5 \times 0.2 \mathrm{~m})$ have been set at the studying plot (Figure 2).

Similar angles have been used to mark the checkpoints which are basic for accuracy estimation of orthophotomap. Such determination of the marked reference points and checkpoint coordinates has been made applying GNSS in real-time kinematics (RTK).

Aerial surveying out of UAV Trimble UX5 has been conducted with the help of digital camera SONY NEX-5R out of $200 \mathrm{~m}$ and $300 \mathrm{~m}$ altitude when the aircraft velocity is $80 \mathrm{~km} / \mathrm{h}$. To set the camera the following parameters have been chosen: regime of surveying set in accordance with priority of moderation, focus is $F / 4.5$, automatic sensitivity ISO exposure is $1 / 1000$ of a second. It must be admitted that the process of piloting is conducted fully automatic. The operator simply controls the apparatus flight and the installed software provides a safe takeoff and landing every time.

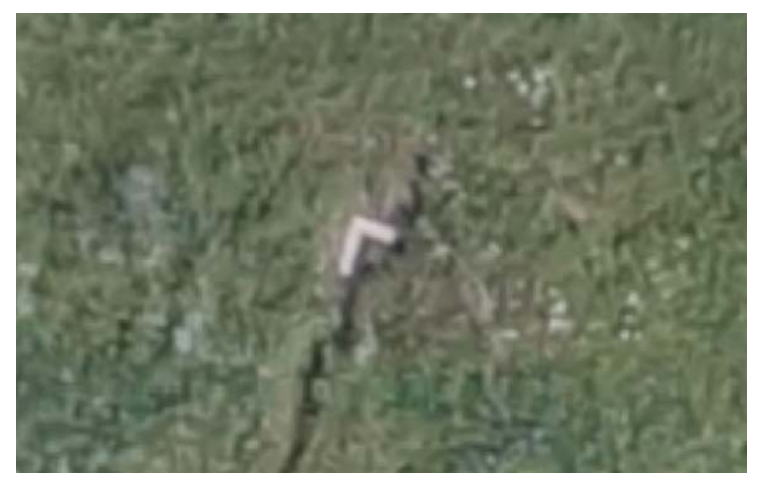

Fig. 2. Marked reference point image

To make orthophotomap photogrammetric module Pix 4D has been used. With it help cloud of points and the TIN-model of the plot (over which aerial surveying is carried out) have been created. Technology of creating the orthophotomap applying Pix 4D software is shown at Fig. 3.

The first step is to download images in Pix 4D format. Then the software determines the high-contrast points at the images and thus, composing plan of the surveying territory has been done by using these points. A three-dimensional map, that is the orthophotomap, is formed on the basis of different images of the same point obtained out of different angles. The second step is to download the reference point coordinates which help to optimize the model. Having completed these steps the program automatically creates the cloud of points and as the result digital situation model and orthophotomap are created.

One of the benefits of the software applying is availability of orthophotomap reduction, which sometimes allows to avoid a great distortion of the image. 


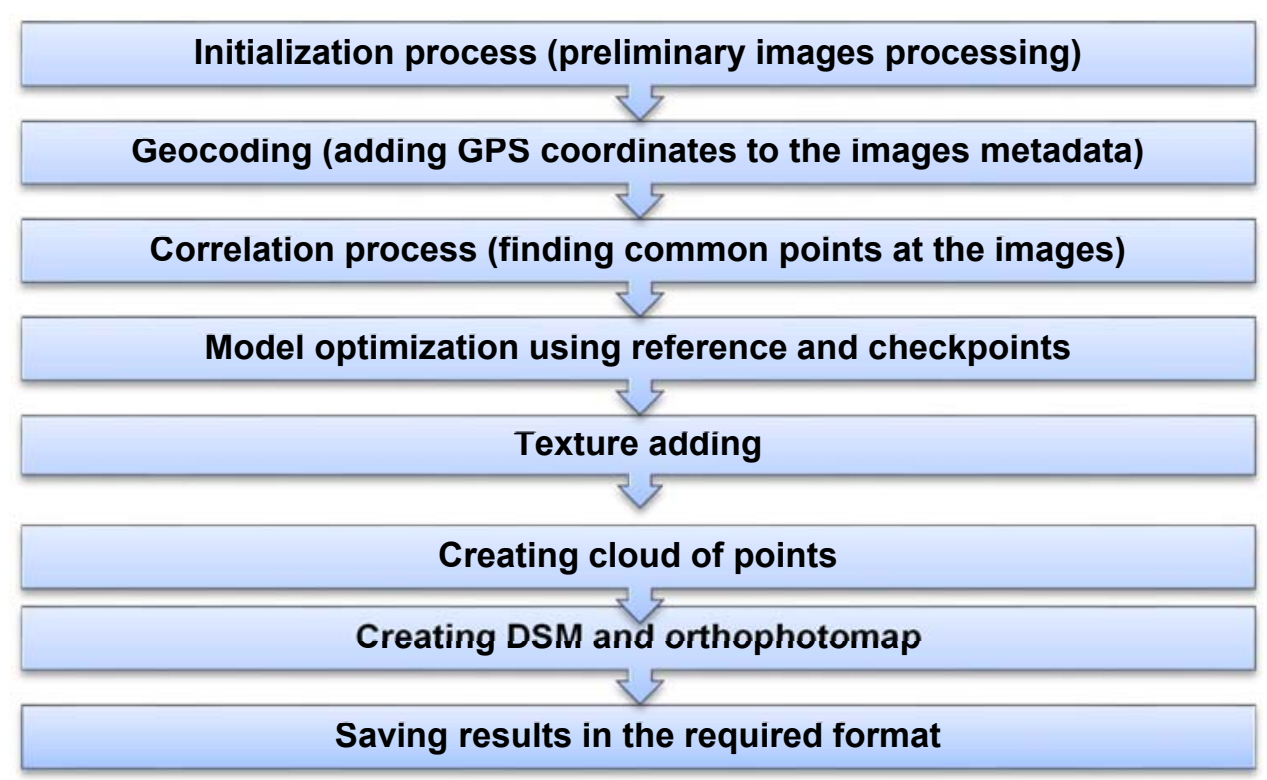

Fig. 3. Technological scheme of creating orthophotomap applying Pix 4D software

After having created the orthophotomap applying digital software and the average square error of the checkpoints coordinates have been determined in accordance to measured coordinates at the territory. The average square error has also been calculated by the formulas (Vovk A. et al., 2015).

\section{Results}

Having analyzed the factors that have an impact on quality of the obtained results it must be said that:

1. A-priori accuracy estimation of the spatial coordinates of the area has been calculated before the aerial surveying works. The results are shown at Table 1.

2. The quality of the output data depends on the factors connected with the complexity of recognition of the checkpoints at the images. Thus, to take the planned altitude references as checkpoints, the distinct territory and area outlines, contrasting to the marked reference points must be chosen. The accuracy of determination of the checkpoint coordinates at the orthophotomap applying the results of UAV aerial surveying has been studied and the result is shown at Table 2.

Comparing the values of the a-priori accuracy estimation and the values of the average square error by the checkpoints it can be concluded that the values of the average square error of the control points do not exceed the values of the a-priori accuracy estimation of spatial coordinates.

3. The quality of the obtained results depends also on the errors of wind direction determination and its velocity at the aerial surveying altitude. As the result, the cutoff, heel and pitch angles have appeared. Thus, the got angle elements of orientation can be analyzed as follows:

- maximum pitch angle is $13^{\circ}$ though the aircraft had a positive slope in accordance to the pitch.

- maximum heel angle is $14^{\circ}$.

- maximum cut- off angle through the routes is $17^{\circ}$.

The obtained slope angles exceed the possible values (Hlotov V. et al., 2014). It is possible to avoid such big values by increasing the aircraft velocity. But it is 
impossible to do this because of its technological characteristics. The only way out is to make aerial surveying when wind is stable or minimum.

Table 1. A-priori value of the average square error of the spatial point coordinates

\begin{tabular}{|c|c|c|c|c|c|c|c|c|c|}
\hline $\begin{array}{c}\text { UAV } \\
\text { model }\end{array}$ & $\begin{array}{c}\text { Name } \\
\text { of the } \\
\text { area }\end{array}$ & $\begin{array}{c}\text { Surveying } \\
\text { altitude } \\
(\mathrm{m})\end{array}$ & $\begin{array}{c}\mathrm{B} \\
(\mathrm{m})\end{array}$ & $1: \mathrm{m}$ & $1: \mathrm{M}$ & $\begin{array}{c}\text { Horizontal } \\
\text { traverse } \\
(\mathrm{m})\end{array}$ & $\begin{array}{c}m_{X} \\
(\mathrm{~m})\end{array}$ & $\begin{array}{c}m_{Y} \\
(\mathrm{~m})\end{array}$ & $\begin{array}{c}m_{z} \\
(\mathrm{~m})\end{array}$ \\
\hline UX5 & Remeniv & 200 & 40 & $1: 13300$ & $1: 1000$ & 0,$5 ; 1,0$ & 0,11 & 0,15 & 0,23 \\
\hline UX5 & Vynnyky & 300 & 60 & $1: 20000$ & $1: 2000$ & 1,0 & 0,26 & 0,38 & 0,43 \\
\hline
\end{tabular}

Table 2. The average square error value by checkpoints

\begin{tabular}{|c|c|c|c|c|c|c|}
\hline $\begin{array}{c}\text { UAV } \\
\text { model }\end{array}$ & $\begin{array}{c}\text { Name of } \\
\text { the area }\end{array}$ & $\begin{array}{c}\text { Number of } \\
\text { checkpoints }\end{array}$ & $\begin{array}{c}\text { Surveying } \\
\text { altitude }(\mathrm{m})\end{array}$ & $m_{X}(\mathrm{~m})$ & $m_{Y}(\mathrm{~m})$ & $m_{z}(\mathrm{~m})$ \\
\hline UX5 & Remeniv & 123 & 200 & 0,10 & 0,07 & 0,21 \\
\hline UX5 & Vynnyky & 113 & 300 & 0,05 & 0,05 & 0,16 \\
\hline
\end{tabular}

Graphic of distribution of the average square error is shown at Figure 4, 5 and 6.

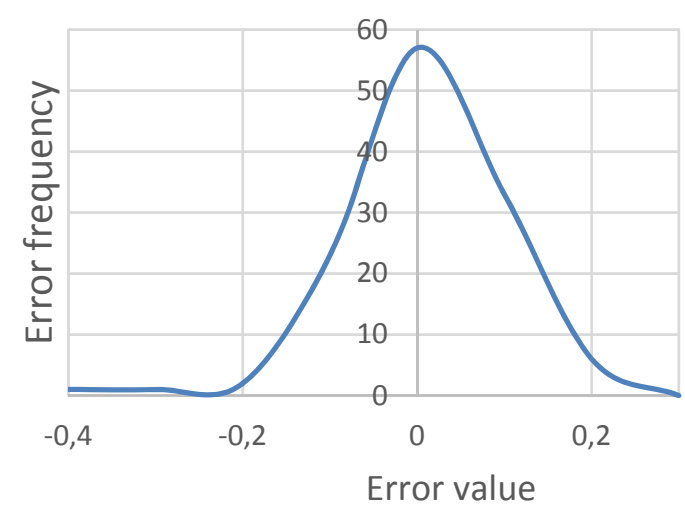

a) Remeniv

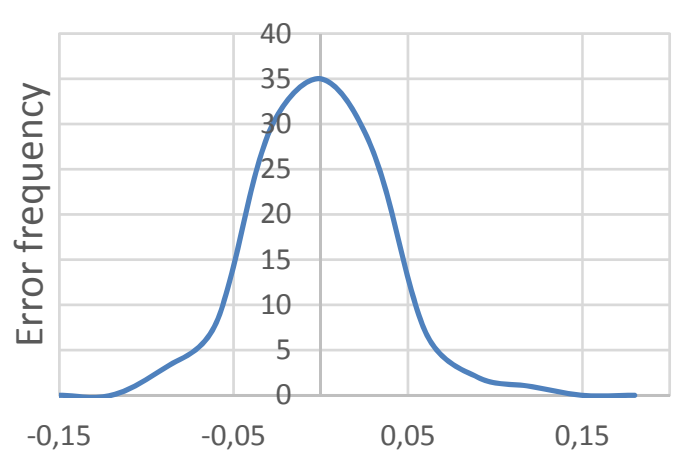

Error value

b) Vynnyky

Fig. 4. Graphic of distribution of the average square error $m_{x}$

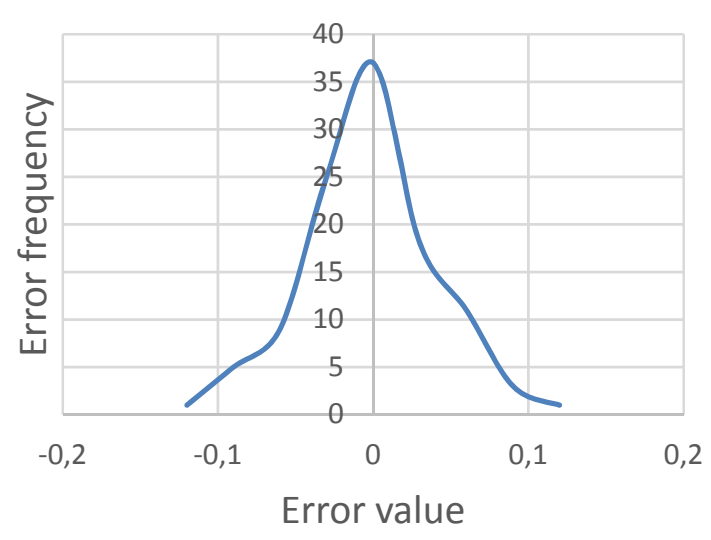

a) Remeniv

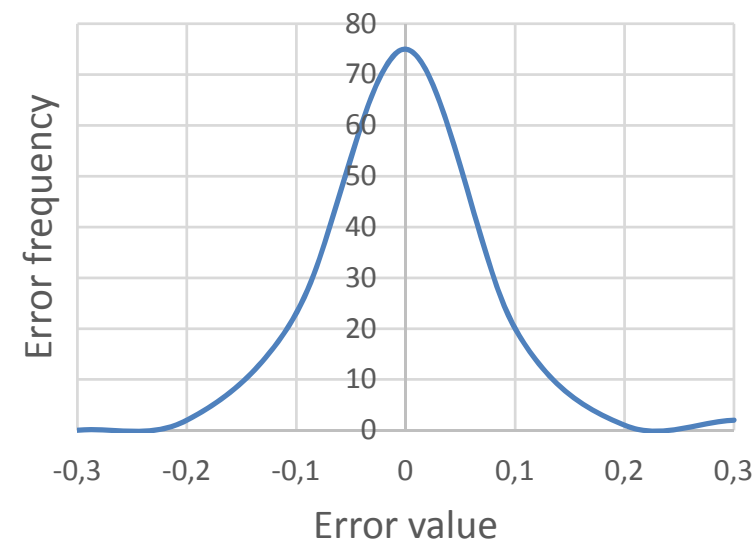

b) Vynnyky

Fig. 5. Graphic of distribution of the average square error $m_{y}$ 


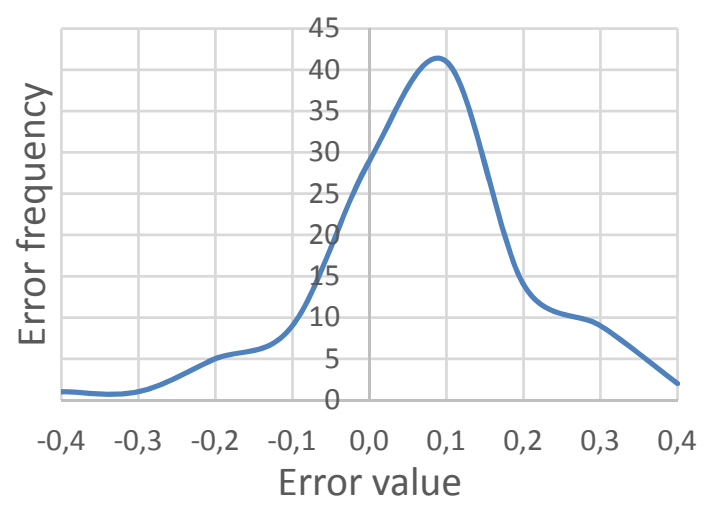

a) Remeniv

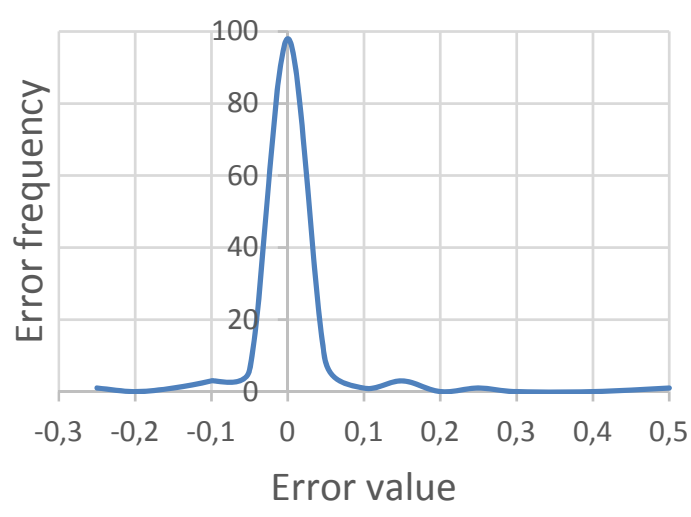

b) Vynnyky

Fig. 6. Graphic of distribution of the average square error $m_{z}$

4. The altitude of UAV must be monitored during aerial surveying. Different scales of the images must not exceed $8 \%$ out of the surveying altitude (http://studopedia.ru/4 68430 nakidnoy-montazh-i-otsenka-kachestva-aterialovaerofotos-emki.html). Thus, the maximum altitude difference is $6.5 \%$, that means it does not exceed the possible value.

5. The ISO value also effects images resolution: the bigger is the value, the bigger is photo-sensitiveness, and as the result, the images will be obtained brighter and fuller in color. But with the matrix sensitivity increasing the presence of speckles at the images is increasing too. The number of speckles at the high ISO values is also increasing. However, it can be hardly done practically because of the changing illumination of the object during the flight, and as the result, the ISO is changing too. Thus, it is necessary to set the ISO in the automatic regime.

6. Special attention must to be paid to the camera exposure, because it has a special effect on the image defect. The less is the exposure, the clearer is the image got during the process of aerial surveying. For example, the exposure value can be calculated by the formula (Burshtynska Kh., 1999):

$$
\sigma_{w}=\frac{W t}{m}
$$

where: $\quad W$ - aircraft velocity $(\mathrm{km} / \mathrm{h})$

$m$ - photography scale denominator

$t$ - moderation

$\sigma_{w^{-}}$linear landslide value

Surveying scale denominator is calculated by the formula:

$$
m=\frac{H}{f} ;
$$

where: $\quad f-$ focus distance

$H$ - aerial surveying altitude

Optimal exposure is determined using the formula (1):

$$
t=\frac{m \sigma_{w}}{W}
$$

The results are shown at Table 3 . 
Table 3. Optimum exposure

\begin{tabular}{|c|c|c|c|c|}
\hline $\begin{array}{c}\text { Name of } \\
\text { the area }\end{array}$ & $\begin{array}{c}\text { Focus } \\
\text { destination } \\
(\mathrm{mm})\end{array}$ & $\begin{array}{c}\text { Aerial surveying } \\
\text { altitude }(\mathrm{m})\end{array}$ & $1: \mathrm{m}(\mathrm{m})$ & $\begin{array}{c}\text { Optimal exposure } \\
(\mathrm{s})\end{array}$ \\
\hline Remeniv & 15 & 200 & $1: 13000$ & $\frac{1}{800}$ \\
\hline Vynnyky & 15 & 300 & $1: 20000$ & $\frac{1}{600}$ \\
\hline
\end{tabular}

The moderation has been set of $1 / 1000$ a second which does not exceed the possible value in the studying.

7. It is necessary to set to the aperture value as minimum as possible. Thus, it provides the opportunity to enhance orthogonality of the image construction. At the same time it must be taken into consideration that dimension of the diaphragm leads to limitation of the light rays, and this in its turn make worse the light of the surveying object image.

8. The quality of the image depends also on the lens distortion, which means distraction of geometric similarity of the object and its image. This aberration is predetermined by inconstant increasing of the light rays reaching the lens at different angles. Such distortion can be considerably reduced by placing the diaphragm between the objective lenses (Burshtynska Kh., 1999). However, the distortion can be ignored, because in Sony NEX-5R its value is reduced due to the compensation program.

The possibilities of UAV application for creating orthophotomaps are increasing every day. The output data can be applied for monitoring the potentially dangerous for people lands and plots of the settlements. That is why, it is very important to monitor the accuracy of the got results.

Based on the analysis and the experimental studies it can be stated, that UAV gives a possibility to collect data more efficiently in comparison with the land surveying methods. Thus, application of UAV Trimble UX5 allows to carry out surveying of built-up areas with the required accuracy for creating orthophotomaps with the following scales 1:2000, 1:1000, 1: 500.

\section{Conclusion}

As the result of experimental work the following conclusion can be made:

1. The chosen object of the study is up-to-date. This fact is confirmed by a great number of foreign and Ukrainian publications dealing with this object.

2. Determinative value of the checkpoints coordinates using images obtained out of UAV Trimble UX-5 does not exceed the a-priori accuracy estimation value. Thus, it the possibility to apply the suggested method for deciding this task.

3. The factors effected the quality of the got results have been analyzed.

4. The prospect of further studying is considered as enhancing of the accuracy estimation of spatial coordinates for creating large-scale topographic maps and orthophotomaps by applying UAV. 


\section{References}

Bajwa, S. \& Tian, L. (2001). Aerial CIR remote sensing for weed density mapping in a soybean field. Transactions of the American Society of Agricultural Engineers, vol. 44(6), pp. 1965- 1974

Вовк, А.; Глотов, В.; Гуніна, А.; Маліцький, А.; Третяк, К.; Церклевич, А. (2015) Аналіз результатів для створення ортофотопланів та цифрових моделей рельєфу із застосуванням БПЛА TRIMBLE UX-5, Міжвідомчий наук.-техн. збірник “Геодезія, картографрія і аерофротознімання", № 81, pp. 89-102, http://ena.Ip.edu.ua:8080/bitstream/ntb/31116/1/10-90-103.pdf

Бурштинська, Х. В.(1999). Аерофотографія: Навчальний підручник. - Львів, 356

Catur, A. R. (2015). The 1st International Symposium on LAPAN-IPB Satellite for Food Security and Environmental Monitoring, The potential of UAV-based remote sensing for supporting precision agriculture in Indonesia. Procedia Environmental Sciences, vol. 24, pp. $245-253$

Coppa, U., Guarnieri, A., Pirotti, F.\& Vettore, A. (2009). Accuracy enhancement of unmanned helicopter positioning with low-cost system. Applied Geomatics, pp.8595

Fernández-Hernandez, J., González-Aguilera, D., Rodríguez-Gonzálvez, P. \& Mancera-Taboada, J. (2014). Image-based modelling from unmanned aerial vehicle (UAV) photogrammetry: an effective, low-cost tool for archaeological applications. Archaeometry, vol. 57, 1 pp. 128-145

Глотов, В. Церклевич, А., Збруцький, О., Колісніченко, В., Прохорчук, О., Карнаушенко, Р., Галецький, В. (2014) Аналіз і перспективи аерознімання 3 безпілотного літального апарата, Збірник наукових праць «Сучасні досягнення геодезичної науки та виробництва», № I(27), с. 131-136, http://ena.lp.edu.ua:8080/bitstream/ntb/31116/1/10-90-103.pdf

Haarbrink, R. \& Eisenbeiss, H. (2008). Accurate DSM production from unmanned helicopter systems. The International Archives of the Photogrammetry, Remote Sensing and Spatial Information Sciences. Vol. XXXVII. Part B1, pp. 1259 - 1264

Hadjimitsis, D., Clayton, C. \& Hope, V. (2004). An assessment of the effectiveness of atmospheric correction algorithms through the remote sensing of some reservoirs. International Journal of Remote Sensing, vol. 25, no. 18, pp. 3651-3674.

Hartley, R. \& Zisserman, A., (2003). Multiple view geometry in computer vision, Cambridge University Press, NewYork, pp. 485-486

Klinken, R., Shepherd, D., Parr, R., Robinson, T. \& Anderson, L. (2007). Mapping mesquite (prosopis) distribution and density using visual aerial surveys. Rangeland Ecology Management, vol. 60, pp. 408-416

Маслянко, В. Я. (2014) Применение 3d-технологий при оперативном планировании и проектировании открытых горных работ. XII всероссийское совещание по проблемам управления ВСПУ-2014, Москва, с. 4337-4347, http://vspu2014.ipu.ru/proceedings/prcdngs/4337.pdf

Mahiny, A. \& Turner B. A (2007). Comparison of Four Common Atmospheric Correction Methods. Photogrammetric Engineering and Remote Sensing, vol.73, No 4, pp. 361-368

Mayr, W. (2013). Unmanned aerial systems-for the rest of us. In: 54th Photogrammetric Week. Institut für Photogrammetrie, Universität Stuttgart, pp. 151-163

Mikrut, S. (2016). Classical photogrammetry and UAV - selected ascpects. The International Archives of the Photogrammetry, Remote Sensing and Spatial 
information sciences, Volume XLI-B1, 2016 XXIII ISPRS Congress, 12-19 July 2016, Prague, Czech Republic, pp. 947 - 952

Mitch, B., Reid, A., Ramos, F. \& Sukkarieh, S. (2010). Airborne Vision-Based Mapping and Classification of Large Farmland Environments. Journal of Field Robotics, vol. 27(5), pp. 632-655

Nebiker, S., Annen, A., Scherrer, M. \& Oesch, D. (2008). A light-weight multispectral sensor for micro UAV - opportunities for very high resolution airborne remote sensing. The International Archives of the Photogrammetry, Remote Sensing and Spatial information sciences, vol. XXXVII, Part B1, Beijing, China, pp. 1193-1200

Petrie, G. (2013). Commercial operation of lightweight UAVs for aerial imaging and mapping. GEOInformatics, vol. 16, pp. 28-39

Rehak, M., Mabillard, R. \& Skaloud, J. (2013). A micro-UAV with the capability of direct georeferencing. International Society for Photogrammetry and Remote Sensing, Spatial Inform., Sci. XL-1/W2, pp. 317-323

Sandmann, H. \& Lertzman, K. (2003). Combining highresolution aerial photography with gradient-directed transects to guide field sampling and forest mapping in mountainous terrain. Forest Science, vol. 49(3), pp. 429-443

Smith, G. M. \& Milton, E., J. (1999). The use of the empirical line method to calibrate remotely sensed data to reflectance. International Journal of Remote Sensing, vol. 20(13), pp. 2653-2662

Steffen, R. \& Förstner, W. (2008). On visual real time mapping for unmanned aerial vehicles. The International Archives of the Photogrammetry, Remote Sensing and Spatial Information Sciences, vol. XXXVII, Part B1, Beijing, China, pp. 57-62

Vallet, J., Panissod, F., Strecha, C. \& Tracol, M. (2011). Photogrammetric performance of an ultra light weight swinglet UAV. International Archives of the Photogrammetry, Remote Sensing and Spatial Information Sciences, vol. XXXVIII1/C22, pp. 253-258

Vasuki, Y., Holden, P., Kovesi, P. \& Micklethwaite, S. (2014). Semi-automatic mapping of geological Structures using UAV-based photogrammetric data: An image analysis approach. Computers \& Geosciences, 2014, vol. 69, pp. 22-32

Whelan, B. \& James, T. (2010). An introduction to Precision Agriculture for Australian grains. Australian Centre for Precision Agriculture, University of Sydney for the Grains Research and Development Corporation.; p. 208

Zhang, N., Wang, V. \& Wang, N. (2002). Precision agriculture - A worldwide overview. Computers and Electronics in Agriculture, No. 36, pp.113-132

Wang, J., Lin, Z. \& Li. C. (2004). Reconstruction of buildings from a single UAV image. XX-th ISPRS Congress Istanbul, Turkey, pp. 100-103

Накидной монтаж и оценка качества материалов аэрофотосъемки

http://studopedia.ru/4_68430_nakidnoy-montazh-i-otsenka-kachestva-materialovaerofotos-emki.html

Trimble UX5 Aerial Imaging Solution:

http://trl.trimble.com/docushare/dsweb/Get/Document-700672/022503-1205D-

UK Trimble UX5 DS MarketSmart 0515 LR.pdf. 


\section{Authors:}

Professor Volodymyr Hlotov ${ }^{1)}$, volodymyr.m.hlotov@lpnu.ua

PhD Alla Hunina ${ }^{1)}$, gunina alla@mail.ru

PhD Zbigniew Siejka ${ }^{2)}$, rmsiejka@cyf-kr.edu.pl

1 Department of Photogrammetry and Geoinformatics, National University Lviv Polytechnic, Institute of Geodesy, Karpinski St. 6, 79013 Lviv, Ukraine

2 Department of Geodesy,

University of Agriculture in Krakow,

Balicka St. 253a, 30-198 Krakow, Poland 